\title{
GENOTYPING OF FOUR LOCI IN HUNGARIAN YELLOW AND BROILER CHICKENS
}

\author{
Klaudia SzAlai, Károly TEMPfli, Erika LenCSÉs-VARGA and Ágnes BALI PAPP ${ }^{*}$ \\ Széchenyi István University, Faculty of Agricultural and Food Sciences, \\ Vár 4, H-9200 Mosonmagyaróvár, Hungary
}

(Received 13 June 2018; accepted 15 February 2019)

\begin{abstract}
Traditional selection has led to remarkable differences in allele frequencies among various chicken breeds. Indigenous and broiler-type chicken populations were genotyped for polymorphisms in thyroid hormone responsive Spot14a, prolactin ( $P R L)$, IGF-binding protein 2 (IGFBP2), and somatostatin (SST) genes in order to determine potential utilisation type-associated allele frequencies. Significant $(\mathrm{P}<0.05)$ differences were detected between Hungarian Yellow and broiler populations for Spot 14 $\alpha, P R L$, and IGFBP2 allele frequencies, whereas the same $S S T$ allele (A) was fixed in both groups. In this study, the most significant associations $(\mathrm{P}<0.05)$ were found between the IGFBP2 genotypes and the measured traits (body weight, carcass weight, breast muscle weight with or without skin, breast muscle weight as a percentage of carcass weight) in the broiler population. The results can be applied for the evaluation of polymorphism effects in the analysed populations; however, contradictory allele effects in different breeds and hybrids indicate the need for cautious marker utilisation in selection programmes.
\end{abstract} morphism

Key words: Chicken, prolactin, Spot $14 \alpha, I G F B P 2$, somatostatin, poly-

In order to identify potential utilisation- and production-related changes in allele frequencies, four polymorphisms in growth-related genes were selected for genotyping, allele frequency and genotype-trait analysis in chicken populations that characteristically differ regarding utilisation and economically important production traits. Allele frequency analyses are often used to identify potential candidate genes and polymorphisms, and are important for the selection of advantageous genotypes.

The intensive selection of broiler chicken has successfully increased growth rate, feed efficiency, carcass yield, and breast muscle percentage. Application of molecular markers associated with meat production is a potential tool to improve production yields.

The thyroid-hormone responsive Spot14 gene (also known as THRSP) was mapped to 1q41-44 in chicken, subsequently a QTL for subcutaneous fatness

\footnotetext{
*Corresponding author; E-mail: bali.papp.agnes@sze.hu; Phone: 0036 (96) 566-612
} 
(Ikeobi et al., 2002) and abdominal fatness (Lagarrigue et al., 2003) were detected close to this locus. The Spot 14 gene was identified as duplicated polymorphic paralogs in chicken, namely Spot $14 \alpha$ and Spot14 $\beta$ (Wang et al., 2004), and consists of two exons (D'André et al., 2010). Spot14 $\alpha$ encodes a small acidic protein, which consists of 132 amino acids, only expressed in lipogenic tissues such as liver, fat and mammary glands in mammals (Cao et al., 2007). Spot14 is implicated as a transcription factor on lipogenic genes promoters, involved in the control of lipogenic enzymes, although the exact molecular mechanism is not clear (Wang et al., 2004). Furthermore, Spot $14 \alpha$ is maintaining a connection between thyroid hormone concentrations and growth (Cao et al., 2007; D'André et al., 2010). Spot 14 mRNA levels are increased by carbohydrate feeding or insulin injection and decreased by high plasma glucagon levels or by a diet rich in polyunsaturated fatty acids (Jump et al., 1993). The expression of Spot $14 \alpha$ mRNA is also regulated by thyroid hormone status (Wang et al., 2004).

Prolactin $(P R L)$ is a polypeptide hormone secreted by the anterior pituitary gland, and has a diverse spectrum of functions including growth, development, metabolism, reproduction, behaviour, and immunoregulation in vertebrates, and plays main roles in several reproductive processes in avian species (Angelier and Chastel, 2009). PRL takes part in several biological functions; however, only limited genotype-growth associations have been reported in chicken (Bhattacharya et al., 2011).

Insulin-like growth factor $1(I G F 1)$ is a candidate gene for growth, body composition, metabolism, fat deposition and skeletal traits in chicken (Zhou et al., 2005). The actions of IGFs are regulated by many factors. The IGF-binding protein type 2 (IGFBP2), as an important member of IGFBPs family, has comprehensive biological functions in vivo via endocrine, autocrine, or paracrine mechanisms, may play an important role in the modification of the growthsupporting effect of circulating IGF1 by producing the IGFBP complex in chicken (Kita et al., 2002), and by regulating IGF transport to tissues and IGF bioavailability to IGF receptors at cell membrane level (Silha and Murphy, 2005). The chicken IGFBP2 gene spans approximately $38 \mathrm{~kb}$ and is located on chromosome 7, consists of four exons, encoding a 275-amino-acid polypeptide hormone, and is regulated by growth hormones (Schoen et al., 1995). The structure and function of the IGFBP2 gene were analysed in detail; however, its association with body weight has not yet been clarified in chickens (Zhao et al., 2015). The chicken IGFBP2 gene is highly expressed in most tissues of embryos, such as liver, muscle, kidney, heart, ovary, brain, intestine, and other tissues (Schoen et al., 1995).

Somatostatin (SST) regulates the secretion of numerous hormones from the mammalian brain, pituitary and peripheral tissues, affects the inhibition of growth hormone secretion from the anterior pituitary (Geris et al., 2000), inhibits pancreatic insulin and glucagon secretion, lipolysis, thyroid function, and stimu- 
lates food intake (Tachibana et al., 2009). The SST gene encodes two biologically active cyclic peptide forms (SST-14 and SST-28). SST-14, which consists of 14 amino acids, is almost fully conserved across vertebrates (Gahete et al., 2008). SST-28, which consists of 28 amino acids, contains a methionine-leucine substitution in chicken compared to mammals (Hasegawa et al., 1984). Although polymorphisms in the SST gene have major effects on growth and body composition in mammals, they are less well characterised in chicken (Nie et al., 2005).

\section{Materials and methods}

\section{Experimental birds and sampling}

The analysed breed and hybrid were: Hungarian Yellow (indigenous breed; $\mathrm{n}=436$; female) and Ross 308 end-product chicken (broiler type hybrid; $\mathrm{n}=$ 103; male). The individual birds involved in this study were randomly selected. Hungarian Yellow chickens used in the present study originated from the genetic resource farm located in Mosonmagyaróvár, managed by the Széchenyi István University. Blood samples were taken into collection tubes (with EDTA as anticoagulant) from wing veins in the Hungarian Yellow population, whereas feather samples were collected from the broilers for the identification of Spot $14 \alpha, P R L$, $I G F B P 2$, SST genotypes, and stored at $-20^{\circ} \mathrm{C}$ pending processing. The weight of 38-day-old broilers was measured before slaughtering, whereas the weight of individual carcasses $(\mathrm{CW})$ was measured before refrigerating. After refrigerating $\left(2 \mathrm{~h}\right.$ at $\left.4{ }^{\circ} \mathrm{C}\right)$, the breast muscle fillets with skin (BMWS) and without skin (BMW), as well as the thighs with skin and bone (TW) were measured, and their percentage related to carcass and live weight were also calculated.

Extraction of DNA from blood and feathers was done with Wizard Genomic DNA Isolation kits (Promega, USA), according to the manufacturer's instructions. DNA concentration and purity were determined using a NanoDrop 2000 spectrophotometer (Thermo Fischer Scientific, USA), and both 260/280 and 260/230 ratios of samples exceeded 1.8.

\section{Genotyping}

Polymerase chain reaction (PCR) and restriction fragment length polymorphism (RFLP) techniques with agarose gel electrophoresis were used to identify genotype. With slight amendments the genotyping methods for the A213C locus in Spot $14 \alpha$ by Cao et al. (2007) and the 24 bp insertion in PRL by Jiang et al. (2005) were applied. Primers were designed and RFLP was constructed for non-synonymous SNPs, the G645T SNP in IGFBP2 and A370G SNP in SST (Table 1). These SNPs were described by Nie et al. (2005). 
Table 1

Primers and restriction enzymes used

\begin{tabular}{|c|c|c|c|c|c|}
\hline Locus & $\begin{array}{c}\text { Sequence } \\
\text { (forward/reverse) }\end{array}$ & $\mathrm{Ta}$ & Sequence ID & $\begin{array}{l}\text { Length } \\
\text { (bp) }\end{array}$ & RE \\
\hline $\begin{array}{l}\text { A213C } \\
\text { exon } 1 \text { of Spot } 14 \alpha\end{array}$ & $\begin{array}{l}\text { CAGGAGGGAGCAGAGGGATAG/ } \\
\text { GGTCGGTCAGAACCTGCTGC }\end{array}$ & 60 & AY568628 & 419 & BsaHI \\
\hline $\begin{array}{l}24 \text { bp insertion } \\
\text { promoter of } P R L\end{array}$ & $\begin{array}{l}\text { GGTGGGTGAAGAGACAAGGA/ } \\
\text { TGCTGAGTATGGCTGGATGT }\end{array}$ & 56 & $\begin{array}{c}\text { FJ663023 } \\
\text { or } \\
\text { FJ434669 }\end{array}$ & $\begin{array}{c}201 \\
\text { and/or } \\
177\end{array}$ & - \\
\hline $\begin{array}{l}\text { G645T } \\
\text { exon } 2 \text { of } I G F B P 2\end{array}$ & $\begin{array}{l}\text { AACAGGCATGAAGGAGATGG/ } \\
\text { CTCGCCAGCACATCAAAGT }\end{array}$ & 52 & U15086 & 315 & BseGI \\
\hline $\begin{array}{l}\text { A } 370 \mathrm{G} \\
\text { exon } 2 \text { of } S S T\end{array}$ & $\begin{array}{l}\text { CCTGTTTTCTCTCCCCTCAC/ } \\
\text { AGTCTTCGCCTCTCGTGGT }\end{array}$ & 55 & X60191 & 330 & BsrBI \\
\hline
\end{tabular}

$\mathrm{Ta}$ - annealing temperature, ${ }^{\circ} \mathrm{C}$; RE - restriction endonuclease; Length - length of PCR products (bp)

The PCR was performed in $25-\mu 1$ mixtures containing $1 \mu \mathrm{l}(200 \mathrm{ng})$ of genomic DNA, $12.5 \mu 1$ 2xPCR Mastermix (Promega, USA; Thermo Fisher Scientific, USA), $1 \mu \mathrm{l}$ of appropriate oligonucleotide primer $(0.4 \mu \mathrm{M}$; Table 1$)$ and nuclease-free water up to $25 \mu \mathrm{l}$ final volume. PCR was applied with the following conditions: $4 \mathrm{~min}$ at $95^{\circ} \mathrm{C}$, followed by 35 cycles of $1 \mathrm{~min}$ at $95^{\circ} \mathrm{C}, 1 \mathrm{~min}$ at annealing temperature (Table 1), $1 \mathrm{~min}$ at $72^{\circ} \mathrm{C}$, and final extension of $4 \mathrm{~min}$ at $72{ }^{\circ} \mathrm{C}$. The PCR products were digested in a total reaction volume of $20 \mu \mathrm{l}$ containing $10 \mu 1$ of the PCR products and $10 \mathrm{U}$ of the appropriate restriction enzyme (Table 1) according to the manufacturers' (Promega and Thermo Fischer Scientific) recommendations. Restriction fragments were electrophoresed on $2 \%$ agarose gels (Agarose, LE, Analytical Grade; Promega) stained with ethidium bromide $(10 \mathrm{mg} / \mathrm{ml}$ stock concentration, $0.5 \mu \mathrm{g} / \mathrm{ml}$ final concentration, Promega), and PCR-RFLP fragment size in each sample was determined by FastRuler Low Range DNA Ladder (Thermo Scientific) under UV illumination. The 24-bp insertion of PRL genotyping was done by loading PCR products straight on 3\% agarose gel.

\section{Statistical analysis}

Hardy-Weinberg Equilibrium (HWE) was tested by Chi-square analysis (SPSS 20.0 for Windows). Differences in allele frequencies between groups were analysed with 2-sided Fisher's exact tests. Heterozygosity (HE) and polymorphism information content (PIC) were calculated according to Nagy et al. (2012). HWE, PIC and HE analyses for SST were not adaptable, since only one allele of the examined locus was present in the investigated populations. Genotype-trait 
associations were evaluated by variance analysis in SPSS 20.0 (ANOVA) using Least Significant Difference (LSD) tests.

\section{Results}

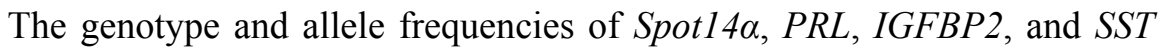
are shown in Table 2. Chi-square test of HWE was not applicable for SST since only allele A was present in the population, whereas other genes were in HWE $(\mathrm{P}>0.05)$.

A significant difference $(\mathrm{P}<0.05)$ was observed between Spot $14 \alpha$ allele frequencies in the examined two populations. Allele A was characterised by a 419-bp fragment, whereas allele C was demonstrated by 319- and 100-bp-long fragments. In the two populations all the three genotypes were found in Spot $14 \alpha$ : $\mathrm{AA}, \mathrm{AC}$ and $\mathrm{CC}$. In both populations a higher frequency of allele $\mathrm{C}$ was represented. The A213C SNP in Spot $14 \alpha$ results in aspartic (allele C) to glutamic (allele A) acid change. The analysed Spot $14 \alpha$ SNP had significant $(\mathrm{P}<0.05)$ effect on breast muscle weight as a percentage of body weight (Table 3 ).

The $P R L$ allele frequencies in Hungarian Yellow chicken were significantly different $(\mathrm{P}<0.05)$ compared to the broiler population (Table 2$)$. In the Hungarian Yellow and the broiler population all the three genotypes were found. Allele I was identified as a 201-bp-long product, whereas allele D was characterised by a 177-bp-long product. In the examined broiler population $P R L$ genotype was significantly $(\mathrm{P}<0.05)$ associated with thigh weight and thigh weight percentage of body weight (Table 3). Regarding most of the measured traits (BW, $\mathrm{CW}$, BMWS, TW), homozygous (DD) chickens surpassed heterozygotes. However, body and carcass weight did not differ significantly $(\mathrm{P}>0.05)$ between heterozygous and homozygous chickens.

The IGFBP2 allele frequencies significantly $(\mathrm{P}<0.05)$ differed between the Hungarian Yellow and the broiler population (Table 2). Two of the three genotypes were found in broilers (GG, GT), while the TT genotype was missing. Allele G was identified by 198- and 117-bp-long fragments, allele T was represented by a 315-bp-long product. Only allele G was found in Hungarian Yellow hens in a previous study (Tempfli et al., 2015).

In the examined broiler population, where two IGFBP2 genotypes were found, birds with heterozygous GT genotype demonstrated significantly $(\mathrm{P}<$ 0.05 ) higher body and carcass weight, breast muscle weight with and without skin and breast muscle weight percentage of carcass weight, than chickens with homozygous (GG) genotype (Table 3).

Allele A at A370G locus in SST was fixed both in the Hungarian Yellow and the Ross 308 populations (Table 2). The fixed genotype was characterised by the uncut 330-bp-long PCR product. 


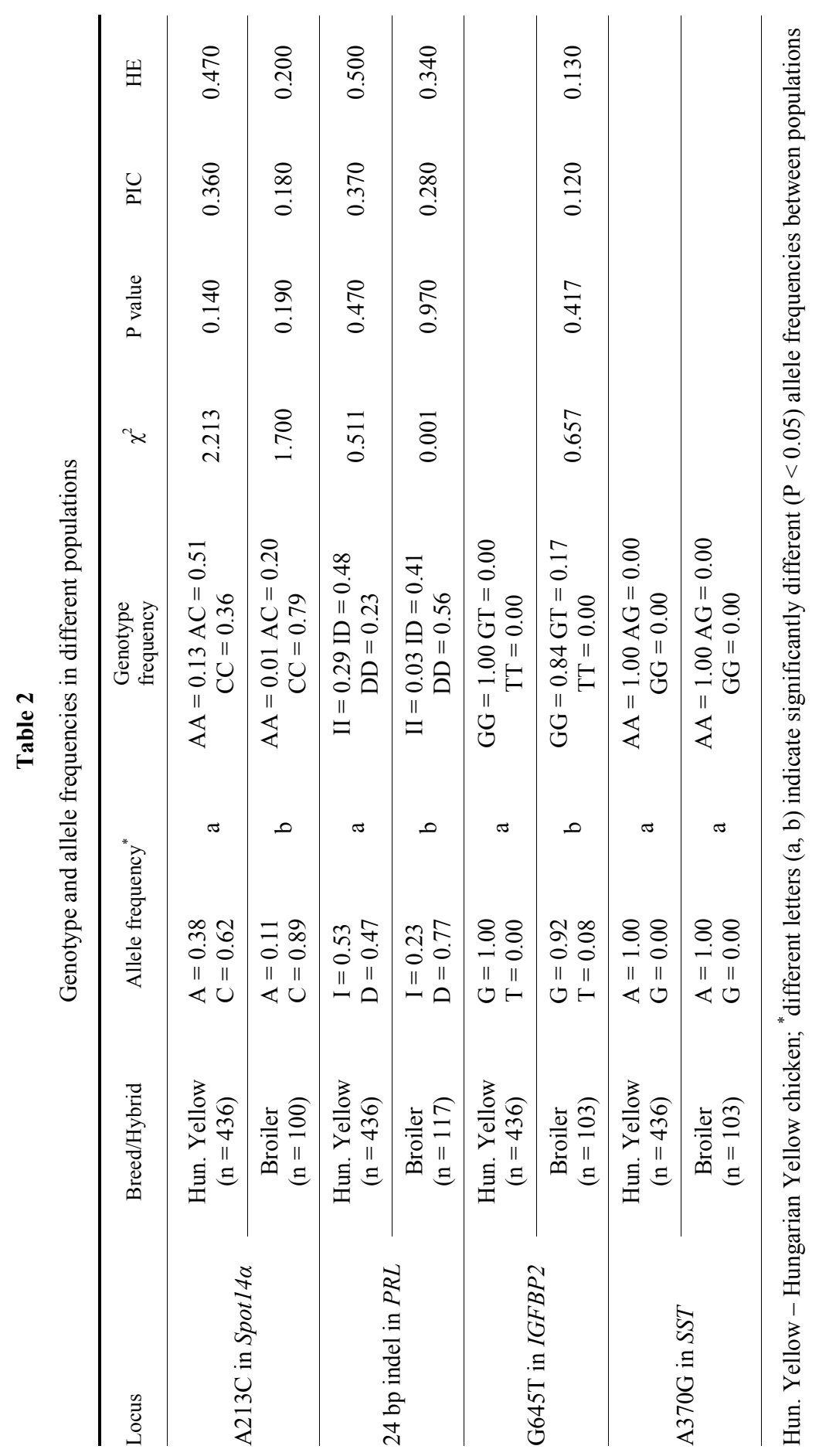


GENOTYPING OF FOUR LOCI IN HUNGARIAN YELLOW AND BROILER CHICKEN 7

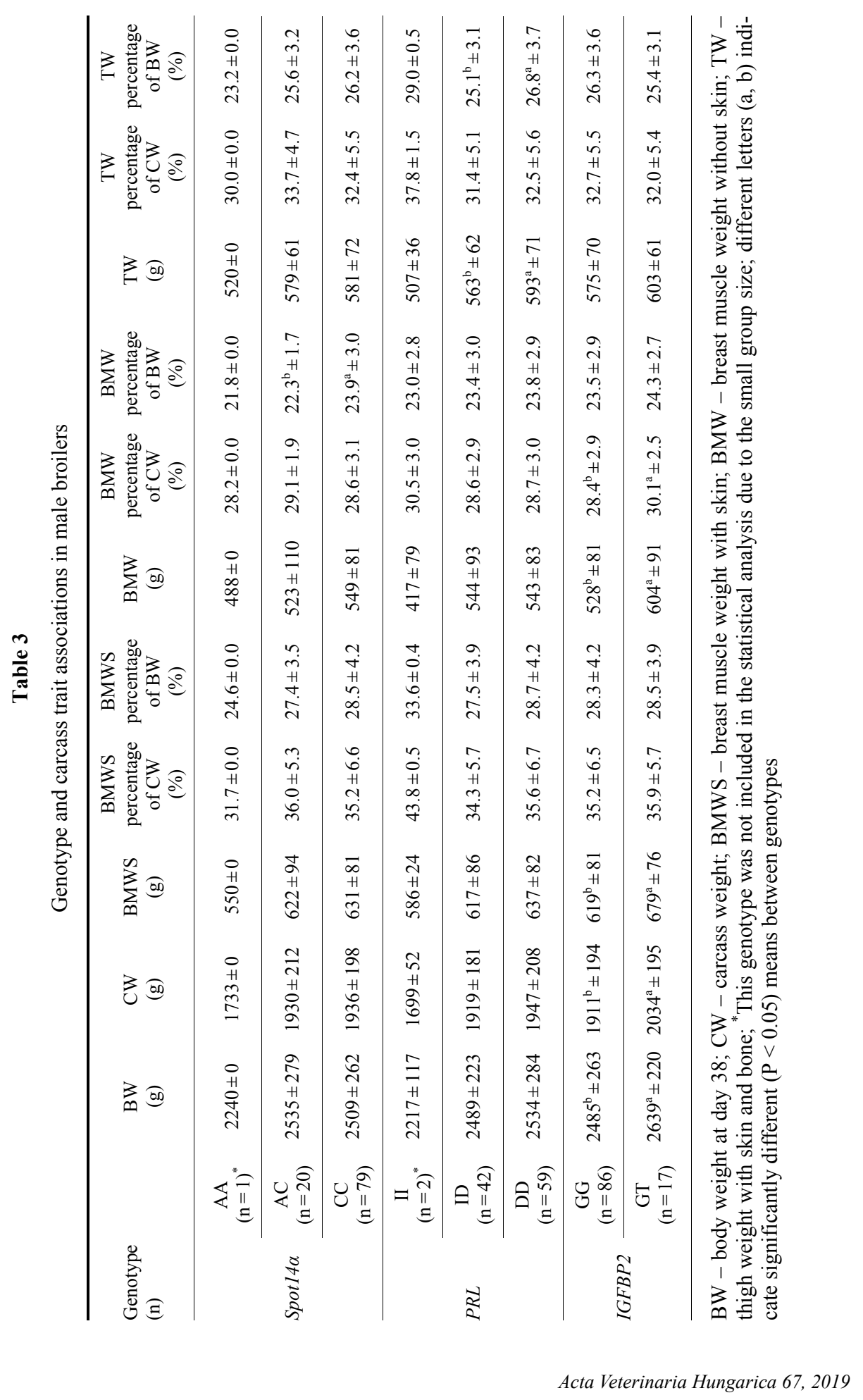




\section{Discussion}

Tempfli et al. (2015) reported a significant association between Spot $14 \alpha$ genotypes and body weight of 8- to 14-, 40- and 45-week-old Hungarian Yellow hens, and allele A was associated with higher body weight in this population. There were no significant differences in body weight at younger ages, and genotype effects were stronger $(\mathrm{P}<0.01)$ at older ages and at higher body weight in the Hungarian Yellow population. In an $\mathrm{F}_{2}$ broiler-layer cross (Cao et al., 2007), which had all the three genotypes, this SNP showed significant $(\mathrm{P}<0.05)$ effects on body weight of 5- to 12-week-old chickens; however, allele $\mathrm{C}$ was associated with increased body weight, since birds with AA genotype had significantly $(\mathrm{P}<$ $0.05)$ lower body and carcass weight than those with CC genotype. There was no association between the polymorphism and the measured body composition traits in the experiment of Cao et al. (2007). In the investigated broiler population significant differences $(\mathrm{P}<0.05)$ were found between the genotypes and breast muscle weight percentage of body weight. In an $\mathrm{F}_{2}$ population of White Recessive Rock and Xinghua breeds, SNPs located in the 5' flanking region of this gene were associated with body weight at younger ages (hatch and 28-day weight; D'André et al., 2010). Based on these contradictory results, a non-direct effect of A213C SNP was proposed, suggesting that the actual causative mutation was nearly linked to the investigated SNP, and was in inverse linkage in the different populations. Before using this SNP in marker-assisted selection programmes, attention must be given to survey the actual direction of the allele substitution effect in the particular breed or line.

In the investigated broiler population significant associations $(\mathrm{P}<0.05)$ were found between the $P R L$ genotypes and the leg weight as well as the leg weight percentage of body weight traits measured. There were no further associations between $P R L$ genotypes and other measured traits. Based on the highly polymorphic $P R L$ promoter, also significant $(\mathrm{P}<0.05) P R L$ haplogroup associations were described in White Leghorn lines with body weight of chickens at sexual maturity and at 16 and 64 weeks of age (Bhattacharya et al., 2011).

Association between IGFBP2 and some growth traits were reported in several chicken populations (Nie et al., 2005; Li et al., 2006). The G645T is nonsynonymous, and significant differences $(\mathrm{P}<0.05)$ were found between polymorphism and body weight in an $\mathrm{F}_{2}$ designed population made up of a reciprocal cross between White Recessive Rock and Xinghua chickens (Lei et al., 2005). Additional associations were found between polymorphisms of IGFBP2 and growth, carcass and body composition traits in several chicken populations ( $\mathrm{Li}$ et al., 2006; Zhao et al., 2015).

In $S S T$ only allele A was found in Hungarian Yellow and Ross 308 broiler populations. This SNP was described by Nie et al. (2005), when Leghorn, White Recessive Rock, Taihe silkies and Xinghua breeds were contrasted. Other reports 
have not been presented about frequency distribution or genotype-trait association of this polymorphism. Probably the clearly preferred allele rapidly fixed in a continuously selected stock. Therefore, further investigations involving other breeds are necessary to assess the effect and frequency of the polymorphism.

The identified breed-specific genotype frequencies are essential markers of the effects of different alleles on the overall performance of chickens. It was concluded that most of the advantageous alleles are nearly fixed in the highly selected broiler population; however, the identified effects of Spot $14 \alpha, P R L$, and $I G F B P 2$ genotypes indicate that there are further possibilities to improve production with specific marker-assisted breeding programmes. Due to contradictions described in this study and the relevant literature in regard to genotype effects on production traits in different breeds and hybrids, it is advised to carefully investigate specific effects in any given population before application of the polymorphisms in marker-assisted selection.

\section{Acknowledgement}

This research was supported by EFOP-3.6.1-16-2016-00017 'Internationalisation, initiatives to establish a new source of researchers and graduates, and development of knowledge and technological transfer as instruments of intelligent specialisations at Széchenyi István University’.

\section{References}

Angelier, F. and Chastel, O. (2009): Stress, prolactin and parental investment in birds: A review. Gen. Comp. Endocr. 163, 142-148.

Bhattacharya, T. K., Chatterjee, R. N., Sharma, R. P., Niranjan, M., Rajkumar, U. and Reddy, B. L. N. (2011): Polymorphism in the prolactin promoter and its association with growth traits in chickens. Biochem. Genet. 49, 385-394.

Cao, Z. P., Wang, S. Z., Wang, Q. G., Wang, Y. X. and Li, H. (2007): Association of Spot14a gene polymorphisms with body weight in the chicken. Poult. Sci. 86, 1873-1880.

D’André, H. C., Yan, W., Wallace, P., Nie, Q., Luo, C., Li, H., Shen, X., Sun, L., Tang, J., Li, W., Zhu, X., Yang, G. and Zhang, X. (2010): Effects of the thyroid hormone responsive spot $14 \alpha$ gene on chicken growth and fat traits. Poult. Sci. 89, 1981-1991.

Gahete, M. D., Durán-Prado, M., Luque, R. M., Martínez-Fuentes, A. J., Vázquez-Martínez, R., Malagón, M. M. and Castano, J. P. (2008): Are sometostatin and cortistatin two siblings in regulating endocrine secretions? In vitro work ahead. Mol. Cell. Endocrinol. 286, 128-134.

Geris, K. L., Meeussen, G., Kühn, E. R. and Darras, V. M. (2000): Distribution of somatostatin in the brain and of somatostatin and thyrotropin-releasing hormone in peripheral tissues of the chicken. Brain Res. 873, 306-309.

Hasegawa, Y., Miyamoto, K., Nomura, M., Igarashi, M., Kangawa, K. and Matsuo, H. (1984): Isolation and amino acid compositions of four somatostatin-like substances in chicken hypothalamic extract. Endocrinology 115, 433-435.

Ikeobi, C. O., Woolliams, J. A., Morrice, D. R., Law, A., Windsor, D., Burt, D. W. and Hocking, P. M. (2002): Quantitative trait loci affecting fatness in the chicken. Anim. Genet. 33, 428-435. 
Jiang, R. S., Xu, G. Y., Zhang, X. Q. and Yang, N. (2005): Association of polymorphisms for prolactin and prolactin receptor genes with broody traits in chickens. Poult. Sci. 84, 839-845.

Jump, D. B., Larke, S. D., MacDougald, O. and Thelen, A. (1993): Polyunsaturated fatty acids inhibit S14 gene transcription in rat liver and cultured hepatocytes. Proc. Natl Acad. Sci. U.S.A. 90, 8454-8458.

Kita, K., Nagao, K., Taneda, N., Inagaki, Y., Hirano, K., Shibata, T., Aman Yaman, M., Conlon, M. A. and Okumura, J. (2002): Insulin-like growth factor binding protein-2 gene expression can be regulated by diet manipulation in several tissues of young chickens. J. Nutr. 132, 145-151.

Lagarrigue, S., Pitel, F., Carre, W., Le Roy, P., Neau, A., Amigues, Y., Simon, J., Vignal, A., Leclercq, B., Cogburn, L. A. and Douaire, M. (2003): An initial QTL scan for abdominal fatness and breast muscle weight in broiler chickens. Plant and Animal Genome Conference XI, San Diego, USA. p. 38.

Lei, M. M., Nie, Q. H., Peng, X., Zhang, D. X. and Zhang, X. Q. (2005): Single nucleotide polymorphisms of the chicken insulin-like factor binding protein 2 gene associated with chicken growth and carcass traits. Poult. Sci. 84, 1191-1198.

Li, Z. H., Li, H., Zhang, H., Wang, S. Z., Wang, Q. G. and Wang, Y. X. (2006): Identification of a single nucleotide polymorphism of the insulin-like growth factor binding protein 2 gene and its association with growth and body composition traits in the chicken. J. Anim. Sci. 84, 2902-2906.

Nagy, S., Poczai, P., Cernák, I., Gorji, A. M., Hegedűs, G. and Taller, J. (2012): PICcalc: an online program to calculate polymorphic information content for molecular genetic studies. Biochem. Genet. 50, 670-672.

Nie, Q., Lei, M., Ouyang, J., Zeng, H., Yang, G. and Zhang, X. (2005): Identification and characterization of single nucleotide polymorphisms in 12 chicken growth-correlated genes by denaturing high performance liquid chromatography. Genet. Sel. Evol. 37, 339-360.

Schoen, T. J., Mazuruk, K., Waldbillig, R. J., Potts, J., Beebe, D. C., Chader, G. J. and Rodriguez, I. R. (1995): Cloning and characterization of a chick embryo cDNA and gene for IGFbinding protein-2. J. Mol. Endocrinol. 15, 49-59.

Silha, J. V. and Murphy, L. J. (2005): Insulin-like growth factor binding proteins in development. Adv. Exp. Med. Biol. 567, 55-89.

Tachibana, T., Cline, M. A., Sugahara, K., Ueda, H. and Hiramatsu, K. (2009): Central administration of somatostatin stimulates feeding behavior in chicks. Gen. Comp. Endocrinol. 161, 354-359.

Tempfli, K., Konrád, Sz., Kovácsné Gaál, K., Pongrácz, L. and Bali Papp, Á. (2015): Prolactin, dopamine receptor D1 and Spot14 $\alpha$ polymorphisms affect production traits of Hungarian Yellow hens. Livest. Sci. 174, 26-30.

Wang, X., Carre, W., Zhou, H., Lamont, S. J. and Cogburn, L. A. (2004): Duplicated Spot 14 genes in the chicken: Characterization and identification of polymorphisms associated with abdominal fat traits. Genetics 332, 79-88.

Zhao, X. H., Li, M. Y., Xu, S. S. and Liu, G. J. (2015): Single nucleotide polymorphisms in IGFBP-2 gene and their associations with body weight traits on Jinghai Yellow chicken. Braz. J. Poult. Sci. 17, 497-502.

Zhou, H., Mitchell, A. D., McMurtry, J. P., Ashwell, C. M. and Lamont, S. J. (2005): Insulin-like growth factor-I gene polymorphism associations with growth, body composition, skeleton integrity, and metabolic traits in chickens. Poult. Sci. 84, 212-219.

\footnotetext{
This is an open-access article distributed under the terms of the Creative Commons Attribution 4.0 International License (https://creativecommons.org/licenses/by/4.0/), which permits unrestricted use, distribution, and reproduction in any medium, provided the original author and source are credited, a link to the CC License is provided, and changes - if any - are indicated. (SID_1)
} 